\title{
HODNOTENIE VYBRANÝCH FAKTOROV KVALITY VNÚTORNÉHO PROSTREDIA V LEED CERTIFIKOVANEJ ADMINISTRATIIVNEJ BUDOVE
}

\author{
EVALUATION OF SELECTED INDOOR ENVIRONMENTAL QUALITY \\ FACTORS IN THE LEED CERTIFIED ADMINISTRATIVE BUILDING
}

\author{
Katarína Harčárová*,1
}

"katarina.harcarova@tuke.sk

${ }^{1}$ Ústav pozemného stavitel'stva, Stavebná fakulta, Technická univerzita v Košiciach, Vysokoškolská 4, 04200 Košice, Slovenská republika

\begin{abstract}
Abstrakt
Prezentovaný príspevok sa zaoberá hodnotením kvality vnútorného prostredia (IEQ) vo vytypovaných kanceláriách novopostavenej LEED certifikovanej administratívnej budovy. Hodnotenie IEQ spočívalo v monitoringu vybraných rizikových IEQ faktorov a dotazníkového prieskumu. Výsledky monitoringu faktorov IEQ ukázali, že monitorované kancelárie spĺn̆ajú požadované legislatívne a LEED limity. Na IEQ v monitorovaných kanceláriách najviac vplýva prítomnost' užívatel'ov a upratovacie práce. Samotní užívatelia hodnotia IEQ v kanceláriách tejto administratívnej budovy pozitívne. Zo získaných výsledkov celkovo vyplýva, že kancelárie príslušnej administratívnej budovy poskytujú užívatel'om zdravé a komfortné vnútorné prostredie, ktoré výrazne nenarúša ich pracovný výkon.
\end{abstract}

\section{Klíčová slova}

Kvalita vnútorného prostredia, zelené budovy, administratívne budovy, LEED certifikácia, dotazníky

\begin{abstract}
The presented paper deals with the assessment of the indoor environmental quality (IEQ) in the selected offices of the newly built LEED certified administrative building. The IEQ assessment consisted of monitoring selected IEQ risk factors and a questionnaire survey. The results of IEQ monitoring showed that the monitored offices meet the required legislative and LEED limits. The presence of occupants and cleaning activities have the greatest impact on IEQ in the monitored offices. The users themselves evaluate the IEQ in the offices of this administrative building positively. Overall, the results obtained show that the offices of the relevant administrative building provide a healthy and comfortable indoor environment that does not significantly disrupt the occupant's work performance.
\end{abstract}

Key words

Indoor environmental quality, green building, office building, LEED certification, questionnaires

\section{1 ÚVOD}

V súčasnosti možno v stavebnom priemysle pozorovat' vzrastajúci záujem o výstavbu zelených budov. Zelené budovy predstavujú trend smerom $\mathrm{k}$ udržatel'nej a ekologickej výstavbe. Tieto budovy spájajú nižšie prevádzkové náklady, zdravšie pracovné prostredie a šetrnost’ k životnému prostrediu [1]. V posledných dvoch desat'ročiach krajiny po celom svete vyvinuli vel'ké množstvo systémov hodnotenia na posudzovanie a certifikáciu zelených budov [2]. Kvalita vnútorného prostredia (IEQ) je zahrnutá skoro vo všetkých certifikačných systémoch zelených budov, ako základný faktor hodnotenia zdravotného rizika pre užívatel'ov vnútorných priestorov [3]. Medzi najčastejšie využivané medzinárodné certifikačné systémy zelených budov patria LEED a BREEAM [4]. V systéme certifikácie LEED je IEQ hodnotená v rámci kategórie "Indoor Environment Quality" a v systéme BREEAM je zaradená do sekcie "Health and Well-being". Súčast'ou hodnotenia IEQ v oboch certifikačných systémoch je aj pravidelné testovanie a vyhodnocovanie rizikových faktorov IEQ prostredníctvom reálnych meraní alebo subjektívneho hodnotenia samotnými užívatel'mi budovy. 
Rizikové faktory IEQ zahŕňajú parametre týkajúce sa kvality vnútorného ovzdušia (IAQ), tepelného, akustického a vizuálneho komfortu [5].

Doteraz bolo vypublikovaných len zopár štúdií, ktoré sa zaoberajú hodnotením IEQ v zelených certifikovaných budovách. Väčšina z nich je zameraná na subjektívne hodnotenie IEQ v týchto budovách, pričom chýbajú tie, ktoré hodnotia reálny stav kvality vnútorného prostredia prostredníctvom meraní rizikových faktorov IEQ [6]. V štúdii podl'a Lee a kol. sa zistilo, že spokojnost' užívatel'ov s budovou a pracovným prostredím nesúvisela s dosiahnutou úrovňou hodnotenia [7]. Podl'a štúdie Lee a kol. administratívne budovy s certifikáciou LEED dosahovali vyššiu spokojnost' užívatel'ov s IAQ ako budovy bez certifikácie LEED. Okrem toho budovy s certifikáciou LEED vykazovali vyššiu výkonnost' užívatel’ov, ktorá súvisela s kvalitou kancelárskeho vybavenia, kvalitou tepelného komfortu, IAQ, čistotou a údržbou budovy v porovnaní s necertifikovanými budovami [8]. Výsledky dotazníkovej štúdie podl'a Altomonte a kol. ukázali, že samotná certifikácia BREEAM zrejme zásadne neovplyvňuje spokojnost' užívatel’ov s budovou a pracovným priestorom. Naopak, užívatelia BREEAM certifikovaných kancelárskych priestorov mali tendenciu byt' menej spokojní s kvalitou ovzdušia a vizuálnym komfortom v porovnaní s užívatel'mi necertifikovaných priestorov [9]. Výsledky štúdie Jin a kol. ukazujú, že spokojnost' užívatel’ov s IEQ v novozrekonštruovanej kancelárskej budove s certifikáciou BREEAM nie je dostatočne dosiahnutá a v kancelárskom prostredí užívatelia uprednostňujú vyššiu teplotu, viac čerstvého vzduchu, menej hluku a viac denného svetla [10].

Ciel'om tejto štúdie je posúdit' stav kvality vnútorného prostredia vo vytypovaných kanceláriách zelenej certifikovanej administratívnej budovy prostredníctvom reálnych meraní rizikových faktorov IEQ a subjektívneho hodnotenia (dotazníkov).

\section{POPIS OBJEKTU A PRIESTOROV}

Novopostavená administratívna budova, v ktorej bol vykonaný monitoring IEQ, je situovaná na východe Slovenska v centre mesta Košice. Táto budova sa radí medzi tzv. zelené budovy ocenené certifikátom LEED GOLD. Budova pozostáva z monolitického železobetónového základu. Zvislá nosná konštrukcia je tvorená železobetónovým skeletom, ktorý je po obvode vyplnený tehlovým murivom. Vodorovná nosná konštrukcia pozostáva zo železobetónových stropných dosiek. Deliace priečky sú sadrokartónové a povrchovo upravené bielou farbou. Povrch podláh v kanceláriách je tvorený anhydridovým poterom. Obvodový plášt' pozostáva zo presklenného hliníkového fasádneho systému. Okná sú otváratel’né s izolačným trojsklom. Vnútorné interiérové dvere sú presklené v hliníkovom ráme. Budova využíva vel'koplošné sálavé podlahové vykurovanie/chladenie. V rámci nadštandardu budova disponuje stropným chladením/kazetovou klimatizáciou. Nadštandardnú kvalitu pracovného prostredia $\mathrm{v}$ budove zabezpečujú najmodernejšie technológie, vrátane zvlhčovačov a zabudovaných snímačov teploty, relatívnej vlhkosti, tuhých častíc a $\mathrm{CO}_{2}$. Vzduch privádzaný do budovy je zbavený nečistôt účinnou filtráciou, tzv. plazmovým efektom - pomocou ionizátorov. Budova je pät’podlažná.

Samotný monitoring prebiehal v dvoch reprezentatívnych kanceláriách nachádzajúcich sa na štvrtom podlaží. Prvá kancelária (Kancelária 1) o rozlohe $85 \mathrm{~m}^{2}$ je užívaná šiestimi osobami. Druhá kancelária (Kancelária 2) o ploche $30 \mathrm{~m}^{2}$ je užívaná dvoma osobami. Obe kancelárie sú vybavené štandardným kancelárskym nábytkom a technikou. V každej kancelárii je umiestnený koberec. Všetky merania prebiehali za prirodzených podmienok v septembri roku 2020. Počas merania dochádzalo v Kancelárii 1 k neustálej výmene vzduchu striedavo prirodzeným spôsobom alebo aktivovaním mechanických systémov. V Kancelárii 2 síce dochádzalo k výmene vzduchu, ale len minimálne. Pre porovnanie bolo vykonané ešte jedno dodatočné meranie v Kancelárii 2 (označená ako Kancelária 2*) za neprítomnosti užívatel’ov. Monitoring bol vykonávaný len štyri mesiace po nast'ahovaní užívatel'ov do priestorov budovy.

\section{METODIKA}

Parametre tepelno-vlhkostnej mikroklímy (teplota vzduchu, relatívna vlhkost' a rýchlost' prúdenia vzduchu) a koncentrácií $\mathrm{CO}_{2}$ boli zaznamenané pomocou multifunkčného zariadenia TESTO 435-4 s príslušnými sondami (Testo, Inc.; Nemecko). Koncentrácie tuhých častíc (PM) dvoch reprezentatívnych frakcií (2,5 a $10 \mu \mathrm{m})$ boli stanovené pomocou prístroja HANDHELD 3016 IAQ (Lighthouse Worldwide Solutions, Inc., USA), ktorý využíva laser-diódový svetelný zdroj a zbernú optiku pre detekciu častíc. Koncentrácie celkových prchavých organických zlúčenín (TVOC) boli stanovené fotoionizačným detektorom s UV lampou ppbRAE 3000 (RAE Systems, Inc.; USA). Pred samotným meraním bola vykonaná dvojbodová kalibrácia - nulová a štandardného referenčného plynu (izobutylénu). Všetky namerané TVOC koncentrácie sú vyjadrené v ekvivalentoch toluénu (korekčný faktor 0,5). Sondy a meracie prístroje boli umiestnené približne v strede miestnosti vo výške $1,1 \mathrm{~m}$ od podlahy. Parametre tepelno-vlhkostnej mikroklímy, tuhých častíc a celkových prchavých organických zlúčenín 
boli zaznamenávané v 1-minútových intervaloch. Stredná radiačná teplota bola meraná v troch výškach pomocou Vernon-Joklovho gul'ového teplomera (priemer gule $\mathrm{d}=0,1 \mathrm{~m}$ ) podl'a ISO 7726 (1998), na základe ktorej bola vypočítaná aj operatívna teplota [11]. Stredná radiačná teplota bola zaznamenávaná iba počas pracovnej doby $\mathrm{v}$ Kanceláriách 1 a 2 . Z dát získaných počas 24-hodinového merania boli samostatne vyhodnotené údaje zaznamenané počas 8-hodinového pracovného času. Štatisticky spracované výsledky boli porovnané s požiadavkami na tepelno-vlhkostnú mikroklímu a limitnými hodnotami zdraviu škodlivých látok vo vnútornom ovzduší uvedenými vo Vyhláške č. 210/2016 Z.z [15]. Zároveň boli výsledky porovnané s LEED v4.1 požiadavkami pre kvalitu vnútorného ovzdušia pre novú výstavbu a interiéry [16], [17]. Aktívny odber vytypovaných prchavých organických zlúčenín (VOCs) prebiehal po dobu šiestich hodín. Vzorky vzduchu boli odoberané do sorpčnej trubičky Anasorb CSC pomocou vzorkovacieho čerpadla SKC PocketPump TOUCH. Po odbere vzoriek boli vzorky analyzované v externom laboratóriu prostredníctvom plynovej chromatografie. Vytypované VOCs zahŕňajú zlúčeniny - toluén, xylény, styrén a tetrachlóretylén - uvedené nielen vo Vyhláške MZ SR 210/2016 Z. z., ale aj na zozname LEED.

Na subjektívne hodnotenie kvality vnútorného prostredia bol použitý modifikovaný dotazník vychádzajúci zo štúdií Cheung a kol. a Lee a kol. [12], [13]. Dotazník obsahoval otázky týkajúce sa základných informácií o respondentovi a otázky zamerané na vnímanie tepelnej pohody, koncentrácií $\mathrm{CO}_{2}$, zápachu (koncentrácie TVOC), prítomnosti PM a celkovej IEQ. V druhej časti sa dotazník zaoberal subjektívnym hodnotením komfortu a pracovného výkonu, ako aj zdravotnými symptómami spozorovanými počas výskytu v budove.

Tepelný komfort bol hodnotený pomocou indexov PMV (stredný tepelný pocit) a PPD (prepodkladané percento nespokojných). Oba indexy boli vypočítané pomocou nástroja CBE Thermal Comfort Tool, ktorý je podrobnejšie popísaný v štúdii podl’a Tartarini a kol. [14]. Index PMV zohl'adňuje šest' parametrov (metabolickú aktivitu a tepelný odpor odevu užívatel'ov, rýchlost' prúdenia vzduchu, strednú radiačnú teplotu, teplotu vzduchu a relatívnu vlhkost'). Z PMV indexu je možné vypočítat' percento l'udí, ktorí by neboli spokojní s konkrétnym tepelným prostredím, tzv. PPD index. V čase merania (na jeseň) sa uvažovalo s tepelným odporom odevu 0,61 clo (nohavice, tričko s dlhým rukávom). Hodnota rýchlosti metabolizmu pri aktivitách vykonávaných posediačky bola v nástroji CBE zvolená ako 1,0 met. Výpočet indexov PMV zahŕňal priemerné hodnoty teploty vzduchu, relatívnej vlhkosti a rýchlosti vzduchu získané z meraní počas 8-hodinovej pracovnej doby.

\section{VÝSLEDKY A DISKUSIA}

Skúmanie kvality vnútorného prostredia spočívalo $\mathrm{v}$ sledovaní vybraných rizikových faktorov IEQ a v subjektívnom hodnotení týchto faktorov samotnými užívatel'mi.

\section{Výsledky 24-hodinového monitorovania}

V tabul'ke 1 sú uvedené štatisticky spracované výsledky IEQ faktorov hodnotených vo vybraných kancelárskych priestoroch počas 24-hodinového monitoringu.

Tab. 1 Vyhodnotenie výsledkov z 24-hodinového monitoringu.

\begin{tabular}{|c|c|c|c|c|c|c|c|c|}
\hline & Štatistika & $\begin{array}{c}\text { Teplota } \\
{\left[{ }^{\circ} \mathrm{C}\right]}\end{array}$ & $\begin{array}{c}\text { Relatívna } \\
\text { vlhkost' [\%] }\end{array}$ & $\begin{array}{l}\text { Rýchlost' prúdenia } \\
\text { vzduchu }[\mathrm{m} / \mathrm{s}]\end{array}$ & $\begin{array}{c}\mathbf{P M}_{2,5} \\
{\left[\mu \mathrm{g} / \mathbf{m}^{3}\right]}\end{array}$ & $\begin{array}{c}\mathbf{P M}_{10} \\
{\left[\mu \mathrm{g} / \mathbf{m}^{3}\right]}\end{array}$ & $\begin{array}{c}\mathrm{CO}_{2} \\
{[\mathrm{ppm}]}\end{array}$ & $\begin{array}{r}\text { TVOC } \\
{\left[\mu \mathrm{g} / \mathrm{m}^{3}\right]}\end{array}$ \\
\hline \multirow{4}{*}{$\underline{V}$} & Priemer & 23,2 & 46,0 & 0,02 & 1,52 & 6,18 & 576 & 389 \\
\hline & Min & 21,4 & 41,6 & 0,00 & 0,53 & 0,54 & 442 & 173 \\
\hline & $\operatorname{Max}$ & 25,8 & 50,9 & 0,26 & 4,08 & 31,39 & 829 & 465 \\
\hline & $S D^{1}$ & 0,96 & 1,84 & 0,02 & 1,01 & 6,88 & 120,62 & 39,89 \\
\hline \multirow{4}{*}{$\underline{D}$} & Priemer & 23,27 & 45,18 & 0,02 & 0,54 & 4,49 & 556 & 849 \\
\hline & Min & 22,50 & 40,70 & 0,01 & 0,28 & 0,37 & 431 & 396 \\
\hline & $\operatorname{Max}$ & 23,80 & 49,40 & 0,09 & 2,66 & 95,05 & 870 & 3192 \\
\hline & $S D^{1}$ & 0,24 & 2,92 & 0,01 & 0,26 & 8,55 & 135,42 & 401,31 \\
\hline \multirow{4}{*}{$\stackrel{*}{\stackrel{*}{\nu}}$} & Priemer & 23,57 & 45,08 & 0,02 & 1,08 & 2,58 & 479 & 425 \\
\hline & Min & 23,00 & 42,80 & 0,01 & 0,45 & 0,72 & 429 & 343 \\
\hline & $\operatorname{Max}$ & 24,80 & 48,60 & 0,07 & 1,83 & 13,84 & 652 & 647 \\
\hline & $S D^{1}$ & 0,49 & 1,26 & 0,00 & 0,42 & 1,95 & 40,89 & 54,23 \\
\hline
\end{tabular}

${ }^{1}$ Smerodajná odchýlka

Výsledky monitoringu parametrov tepelno-vlhkostnej mikroklímy naznačujú, že medzi vybranými kanceláriami sú len minimálne rozdiely. Požiadavky Vyhlášky č. 210/2016 Z.z. pre relatívnu vlhkost’ (30-70 \%) 
a rýchlost' prúdenia vzduchu $(\leq 0,2 \mathrm{~m} / \mathrm{s})$ boli splnené v oboch monitorovaných kanceláriách, vrátane Kancelárie $2 *$. Rovnako tak nebola prekročená ani legislatívna požiadavka pre koncentrácie $\mathrm{PM}_{10}\left(50 \mu \mathrm{g} / \mathrm{m}^{3}\right)$ daná pre 24- hodinovú expozíciu. Certifikačný systém LEED v4.1 pre novú výstavbu a interiéry udáva limitné hodnoty pre koncentrácie $\mathrm{PM}_{2,5}\left(\leq 12 \mu \mathrm{g} / \mathrm{m}^{3}\right), \mathrm{PM}_{10}\left(\leq 50 \mu \mathrm{g} / \mathrm{m}^{3}\right)$ a TVOC $\left(\leq 500 \mu \mathrm{g} / \mathrm{m}^{3}\right)$. Hodnoty priemerných koncentrácí́ $\mathrm{PM}_{2,5}$ a $\mathrm{PM}_{10}$ neprekročili požadovaný LEED limity. V prípade TVOC bolo prekročenie požadovaného LEED limitu o $41 \%$ pozorované jedine v Kancelárii 2. V porovnaní s Kanceláriou 1 bola v Kancelárii 2 zistená o 54 \% vyššia prítomnost' TVOC.

Priebeh koncentrácií TVOC v jednotlivých v kanceláriách počas celkovej doby monitoringu je znázornený na Obr. 1 (vl’avo). Prudký nárast koncentrácií TVOC bol zaznamenaný v Kancelárii 2 po pracovnej dobe medzi 17:05 a 17:35 hod z dôvodu upratovacích prác. Odporúčaná limitná hodnota pre koncentrácie $\mathrm{CO}_{2}$ podl'a Pettenkofera $(<1000 \mathrm{ppm})$ nebola prekročená ani v jednej z užívaných kancelárií [20]. Z Obr. 1 (vpravo) vyplýva, že najvyššie koncentrácie $\mathrm{CO}_{2}$ boli zaznamenané počas pracovnej doby, ked' sa v kanceláriách nachádzali užívatelia. Za ich neprítomnosti sa koncentrácie $\mathrm{CO}_{2}$ pohybovali v rozmedzí od 400-600 ppm. Koniec pracovnej doby je $\mathrm{v}$ grafoch naznačený modrou zvislou čiarou.
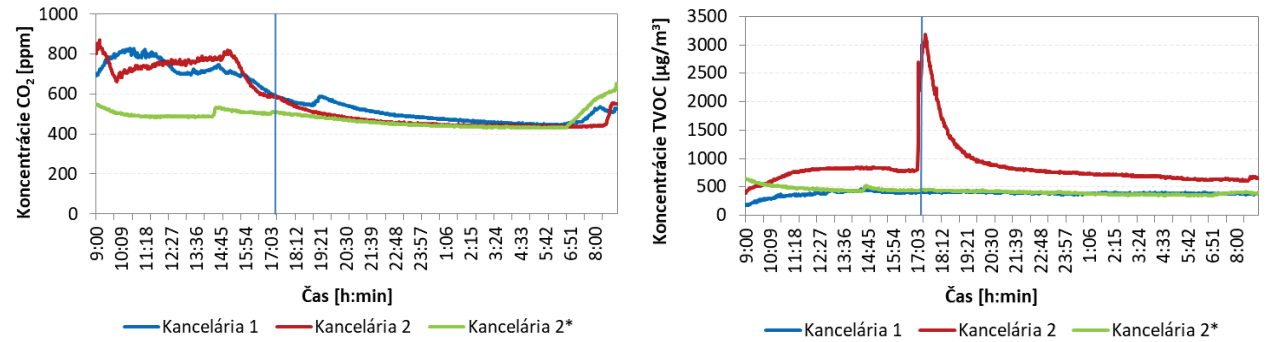

Obr. 1 Priebeh koncentrácií TVOC (vl’avo) a $\mathrm{CO}_{2}$ (vpravo) počas 24-hodinového monitoringu.

Z Obr. 2 je zrejmé, že upratovacie práce v Kancelárii 2 neovplyvnili len koncentrácie TVOC, ale aj koncentrácie tuhých častíc. Prítomnost' osoby v Kancelárii 2 počas upratovania sa prejavila aj na miernom zvýšení koncentrácií $\mathrm{CO}_{2}$ (označené šípkou). Upratovacie práce $\mathrm{v}$ tejto kancelárii spočívali vo vysávaní kobercov a aplikovaní čistiacich prostriedkov. V Kancelárii 1 nebolo pozorované extrémne zvýšenie koncentrácií TVOC a tuhých častíc vplyvom upratovacích prác, nakol'ko v čase monitoringu v tejto kancelárii žiadne upratovacie práce neprebiehali.

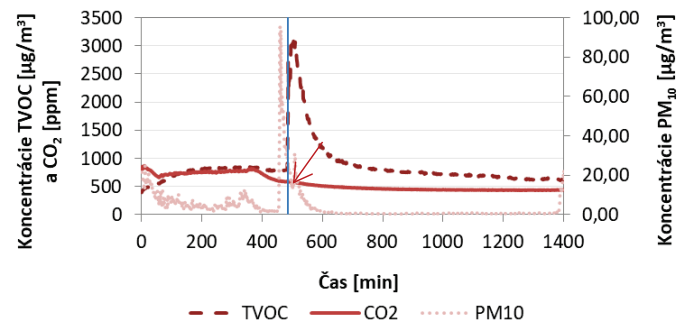

Obr. 2 Koncentrácie znečist’ujúcich látok vo vnútornom ovzduší zaznamenané v Kancelárii 2 počas 24 hodín.

\section{Výsledky získané počas 8-hodinovej pracovnej doby}

Počas pracovnej doby od 9:00 do 17:00 sa teplota vnútorného ovzdušia v Kancelárii 1 pohybovala v rozmedzí od 21,4 do $25,8{ }^{\circ} \mathrm{C}$ a hodnoty relatívnej vlhkosti od 41,6 do 50,9\%. Maximálna rýchlost' prúdenia vzduchu dosahovala hodnotu $0,26 \mathrm{~m} / \mathrm{s}$. Priemerné hodnoty boli $24,2{ }^{\circ} \mathrm{C}$ pre teplotu ovzdušia, $45,9 \%$ pre relatívnu vlhkost' a $0,00 \mathrm{~m} / \mathrm{s}$ pre rýchlost' prúdenia vzduchu. V Kancelárii 2 sa počas 8 -hodinovej pracovnej doby pohybovala teplota vnútorného ovzdušia od 22,5 do $23,8{ }^{\circ} \mathrm{C}$, hodnoty relatívnej vlhkosti od 40,7 do $45,2 \%$ a hodnoty rýchlosti prúdenia vzduchu od 0,01 do $0,09 \mathrm{~m} / \mathrm{s}$. Priemerné hodnoty boli $23,50{ }^{\circ} \mathrm{C}$ pre teplotu vnútorného ovzdušia, $41,73 \%$ pre relatívnu vlhkost' a $0,02 \mathrm{~m} / \mathrm{s}$ pre rýchlost' prúdenia vzduchu. Počas typického pracovného intervalu (9:00-17:00), kedy v tejto kancelárii neboli prítomní užívatelia sa teplota vnútorného ovzdušia rôznila od 23,4 do $24,8{ }^{\circ} \mathrm{C}$, hodnoty relatívnej vlhkosti od 42,8 do $48,6 \%$ a relatívnej vlhkosti vzduchu od 0,02 do 0,07 $\mathrm{m} / \mathrm{s}$. Priemerná hodnota teploty vnútorného ovzdušia bola $24,17{ }^{\circ} \mathrm{C}$, relatívnej vlhkosti $45,24 \%$ a rýchlosti prúdenia vzduchu $0,02 \mathrm{~m} / \mathrm{s}$. 
Koncentrácie $\mathrm{PM}_{2,5}$ sa počas ôsmich hodín užívania Kancelárie 1 pohybovali v rozmedzí od 1,25 do 4,08 $\mu \mathrm{g} / \mathrm{m}^{3}$, zatial' čo koncentrácie $\mathrm{PM}_{10}$ dosahovali hodnoty od 2,01 do $26,57 \mu \mathrm{g} / \mathrm{m}^{3}$. Priemerná koncentrácie tuhých častíc bola $2,74 \mu \mathrm{g} / \mathrm{m}^{3}$ pre $\mathrm{PM}_{2,5}$ a $14,09 \mu \mathrm{g} / \mathrm{m}^{3}$ pre $\mathrm{PM}_{10}$. V dobe užívania Kancelárie 2 dosahovali priemerné koncentrácie $\mathrm{PM}_{2,5}$ hodnotu $0,45 \mu \mathrm{g} / \mathrm{m}^{3}$. Priemerná koncentrácia $\mathrm{PM}_{10}$ bola $6,16 \mu \mathrm{g} / \mathrm{m}^{3}$. Koncentrácie $\mathrm{PM}_{2,5} \mathrm{sa}$ pohybovali od 0,28 do $0,78 \mu \mathrm{g} / \mathrm{m}^{3}$ a koncentrácie $\mathrm{PM}_{10}$ od 1,12 do $24,69 \mu \mathrm{g} / \mathrm{m}^{3}$. Za neprítomnosti užívatel'ov, počas štandardnej pracovnej doby, sa koncentrácie $\mathrm{PM}_{2,5}$ pohybovali od 0,45 do $0,85 \mu \mathrm{g} / \mathrm{m}^{3}$ a koncentrácie $\mathrm{PM}_{10}$ od 0,72 do $13,84 \mu \mathrm{g} / \mathrm{m}^{3}$. Priemerné koncentrácia $\mathrm{PM}_{2,5}$ bola $0,60 \mu \mathrm{g} / \mathrm{m}^{3}$. V prípade $\mathrm{PM}_{10}$ dosahovala priemerná koncentrácie hodnotu $2,68 \mu \mathrm{g} / \mathrm{m}^{3}$.

Vo všetkých troch kanceláriách boli počas 8-hodinovej pracovnej doby sledované aj koncentrácie $\mathrm{CO}_{2}$ a TVOC. V Kancelárii 1 sa koncentrácie $\mathrm{CO}_{2}$ rôznili od 604 do 829 ppm a koncentrácie TVOC od 173 do 465 $\mu \mathrm{g} / \mathrm{m}^{3}$. Priemerná koncentrácia $\mathrm{CO}_{2}$ bola $733 \mathrm{ppm}$, kým koncentrácia TVOC dosahovala v priemere $378 \mu \mathrm{g} / \mathrm{m}^{3}$. Naopak v Kancelárii 2 dosahovala najnižšia zaznamená koncentrácia $\mathrm{CO}_{2}$ hodnotu 585 ppm a najvyššia hodnotu 870 ppm. Najnižšia koncentrácie TVOC dosahovala hodnotu $396 \mu \mathrm{g} / \mathrm{m}^{3}$ a najvyššia hodnotu $851 \mu \mathrm{g} / \mathrm{m}^{3}$. Priemerná koncentrácia $\mathrm{CO}_{2}$ bola v tejto kancelárii 736 ppm a priemerná koncentrácia TVOC bola $752 \mu \mathrm{g} / \mathrm{m}^{3}$. Bez prítomnosti užívatel'ov v Kancelárii 2 sa koncentrácie $\mathrm{CO}_{2}$ pohybovali od 482 do 550 ppm s priemernou koncentráciou 501 ppm. V priemere dosahovala koncentrácia TVOC v Kancelárii $2 *$ hodnotu $481 \mu \mathrm{g} / \mathrm{m}^{3}$, pričom najnižšia zaznamenaná koncentrácia TVOC mala hodnotu $420 \mu \mathrm{g} / \mathrm{m}^{3}$ a tá najvyššia $647 \mu \mathrm{g} / \mathrm{m}^{3}$.

Ani počas 8-hodinovej pracovnej doby sa priemerné hodnoty parametrov tepelno-vlhkostnej mikroklímy od seba výrazne nelíšili. Počas pracovnej doby bola navyše zaznamenávaná stredná radiačná teplota, ktorá bola použitá pri výpočte operatívnej teploty. Získané hodnoty operatívnej teploty pre Kancelárie 1 a 2 sa nachádzali v rámci optimálnych $\left(20-24{ }^{\circ} \mathrm{C}\right)$ a prípustných $\left(18-26^{\circ} \mathrm{C}\right)$ legislatívnych limitov. Koncentrácie $\mathrm{CO}_{2}$ sa v oboch obsadených kanceláriách držali na rovnakých úrovniach. Ked’že merania prebiehali za prirodzených podmienok (pri aktívnej ventilácii) boli tieto hodnoty zároveň pod odporúčanou limitnou hodnotou 1000 ppm. Od 9:00 do 17:00 bola v Kancelárii 2 zistená o 50\% vyššia prítomnost’ TVOC ako v Kancelárii 1 a o $36 \%$ vyššia priemerná koncentrácia TVOC ako v Kancelárii 2*. LEED limitná hodnota bola v Kancelárii 2 prekročená o 34\%. V tomto časovom úseku v Kancelárii 2 ešte neprebiehali upratovacie práce a zvýšená koncentrácia TVOC skôr súvisí s prítomnost'ou osôb a so zníženou intenzitou výmeny vzduchu v tejto miestnosti. Výskyt TVOC v Kancelárii 2* pochádza z kancelárskeho vybavenia a techniky, poprípade sa čast' TVOC uvol’ňuje z materiálov aplikovaných pri výstavbe budovy. Koncentrácie tuhých častíc $\left(\mathrm{PM}_{2,5}\right.$ a $\left.\mathrm{PM}_{10}\right)$ dosahovali najvyššie úrovne v Kancelárii 1 , čo súvisí s jej vyššou obsadenost'ou. Ku kolísaniu koncentrácii tuhých častíc $\mathrm{v}$ jednotlivých kanceláriách dochádzalo najmä pri pohybe užívatel'ov po miestnosti. Aj napriek tomu sa však koncentrácie $\mathrm{PM}_{2,5}$ a $\mathrm{PM}_{10}$ počas celej doby užívania kancelárie, či už v Kancelárii 1 alebo 2, nachádzali pod požadovanými legislatívnymi (len $\mathrm{PM}_{10}$ ) a LEED limitmi. Okrem zaznamenávania koncentrácií TVOC, boli zároveň v každej kancelárii odobrané vzorky ovzdušia pre analýzu vytypovaných zdraviu škodlivých VOCs, konkrétne toluénu, xylénov, styrénu a tetrachlóretylénu. Výsledky laboratórnej analýzy ukázali, že vytypované prchavé organické zlúčeniny sa nachádzali pod limitmi stanovenia (LOQ), a teda ani v tomto prípade nedošlo $\mathrm{k}$ prekročeniu požadovaných LEED, či legislatívnych limitov.

\section{Subjektívne hodnotenie IEQ}

Do dotazníkovej štúdie sa celkovo zapojilo 12 užívatel'ov ( 8 žien a 4 muži). Títo užívatelia uviedli, že na svojom pracovisku trávia 40-50 hodín týždenne, čo je približne 8-9 hodín denne. Väčšina respondentov bola mladších ako 40 rokov, okrem dvoch mužov, ktorí spadali do vekovej kategórie 41-50 rokov. Zo všetkých respondentov boli len dvaja fajčiari. Dve posudzované kancelárie boli užívané nefajčiarmi. Všetci opýtaní vykonávali prácu administratívneho typu.

Pri subjektívnom hodnotení tepelno-vlhkostnej mikroklímy bolo $67 \%$ z celkového počtu opýtaných spokojných s teplotou vo vnútornom prostredí a až $83 \%$ opýtaných vyjadrilo spokojnost' s vlhkost’ou vo vnútornom prostredí. Pät’desiat percent opýtaných nevnímalo žiadny prievan, zvyšok opýtaných vníma na svojom pracovisku l'ahký, prípadne mierny prievan.

Vypočítané hodnoty PMV a PPD indexov pre Kancelárie 1 a 2 sú zhrnuté v tabul'ke 2.

Tab. 2 Výsledné hodnoty PMV a PPD indexov.

\begin{tabular}{ccc}
\hline & Kancelária 1 & Kancelária 2 \\
\hline Stredná radiačná teplota $\left[{ }^{\circ} \mathrm{C}\right]$ & 24,5 & 22,8 \\
PMV & $-0,37$ & $-0,81$ \\
PPD [\%] & 8 & 19 \\
Kategória & II & IV \\
\hline
\end{tabular}

Podl'a normy ISO 7730 (2005) možno vnútorné prostredie považovat' za komfortné, ak sa získané hodnoty ukazovatel'a PMV pohybujú v rozmedzí $-0,5$ až $+0,5$, čo predstavuje približne $10 \%$ nespokojných [18]. 
Výsledky ukazujú, že na rozdiel od Kancelárie 2 (IV. kategória - nižšia úroveň očakávania) možno podmienky tepelnej pohody v Kancelárii 1 (II. kategória - stredná úroveň očakávania) považovat' za komfortné. Podl’a EN 16798-1 (2019) nižšia úroveň očakávaní nepredstavuje žiadne zdravotné riziko pre užívatel'ov, môže však znižovat' ich komfort [19].

Z celkového počtu opýtaných $34 \%$ uviedlo, že vnútorné ovzdušie z hl'adiska koncentrácií $\mathrm{CO}_{2}$ vníma ako čerstvé a až 58\% ako mierne čerstvé. Čo sa týka zápachu väčšina užívatel’ov nevnímalo vo vnútornom ovzduší žiaden zápach (67\%), poprípade vnímalo len slabý zápach. Na otázku súvisiacu s prítomnost’ou tuhých častíc (prachu) vo vnútornom ovzduší odpovedalo 59\% opýtaných, že na svojom pracovisku nevníma žiaden prach. Zvyšok považuje prítomnost' prachu na pracovisku za slabú alebo prijatel'nú. Až $45 \%$ užívatel'ov považuje úroveň osvetlenia kancelárie za vel'mi vysokú a zvyšných $58 \%$ za vysokú alebo prijatel'nú. Vo všeobecnosti užívatelia vyjadrili spokojnost' s IEQ na svojom pracovisku. Všetci užívatelia sa zhodli, že z hl'adiska svojich osobných preferencií hodnotia vnútorné prostredie skôr ako prijatel'né ako neprijatel'né.

Výsledky subjektívneho hodnotenia vplyvu faktorov kvality vnútorného prostredia na výkonnost' užívatel'ov sú znázornené na Obr. 3 (vl'avo). Až 41\% opýtaných uviedlo, že teplota vnútorného vzduchu mierne zvyšuje ich výkonnost'; $67 \%$ uviedlo, že vplyv vlhkosti považuje za neutrálnu vo vzt’ahu k ich vnímanému výkonu; celkovo 59\% opýtaných uviedlo, že prievan neovplyvňuje ich výkonnost', prípadne ich výkonnost' znižuje len mierne. Presne 50\% opýtaných uviedlo, že IAQ (vnímanie $\mathrm{CO}_{2}$ a zápachu) považuje z hl'adiska ich výkonnosti za neutrálne. $58 \%$ opýtaných uviedlo, že prach (prítomnost' $\mathrm{PM}_{10}$ ) na pracovisku neovplyvňuje ich výkonnost'.

Na Obr. 3 (vpravo) sú znázornené výsledky subjektívneho hodnotenia vplyvu faktorov IEQ na komfort užívatel'ov. Väčšina respondentov hodnotila vnútornú teplotu, vlhkost', vnímanie prievanu a kvalitu vnútorného ovzdušia ( $\mathrm{PM}_{10}$ zvlášt') ako vel'mi komfortné až komfortné.
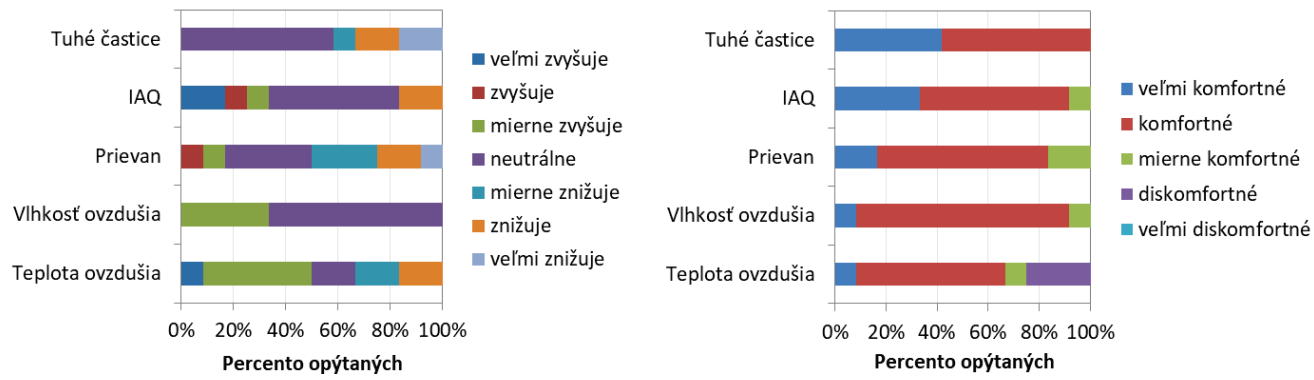

Obr. 3 Subjektívne hodnotenie vplyvu faktorov IEQ na výkonnost' (vl’avo) a komfort (vpravo) užívatel'ov.

Podrobné vyhodnotenie zdravotných symptómov prejavujúcich sa u užívatel'ov počas výskytu v budove je znázornené na Obr. 4.

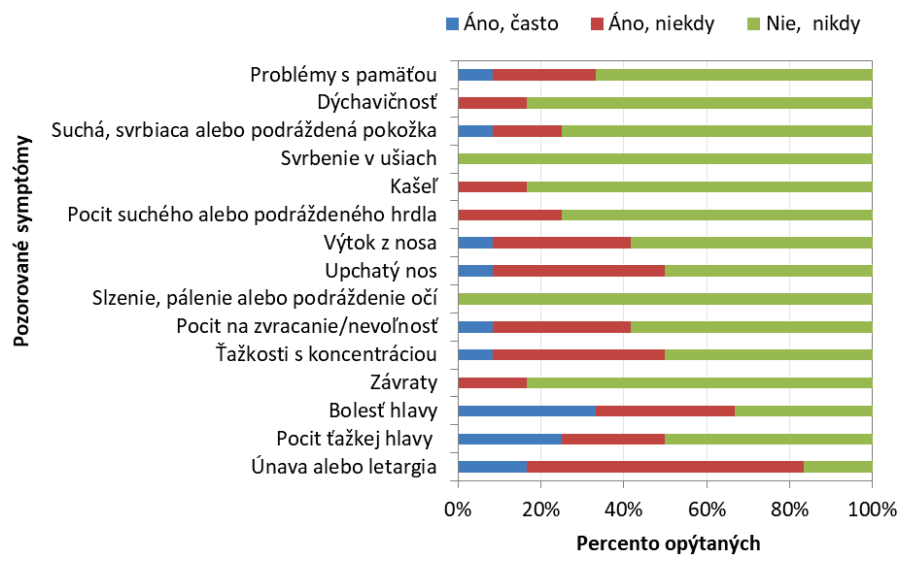

Obr. 4 Zdravotné príznaky pozorované počas pobytu v budove.

Medzi najčastejšie zdravotné symptómy, ktoré pocit’ovali zamestnanci počas výskytu na svojom pracovisku patrili bolest' hlavy, únava a letargia. Presne $50 \%$ opýtaných sa vyjadrilo, že má pocit t’ažkej hlavy, t’ažkosti 
s koncentráciou alebo pocit’ujú slzenie, pálenie alebo podráždenie očí. Ak vezmeme do úvahy predchádzajúce odpovede týkajúce sa vnímania IEQ, je možné tvrdit', že zdravotné príznaky prejavujúce sa u väčšiny respondentov súvisia skôr s typom vykonávanej práce ako s IEQ.

\section{ZÁVER}

V tejto štúdii bola hodnotená kvalita vnútorného prostredia v novopostavenej LEED certifikovanej administratívnej budove. $\mathrm{V}$ rámci hodnotenia kvality vnútorného prostredia $\mathrm{v}$ tejto administratívnej budove boli sledované rizikové faktory IEQ $\mathrm{v}$ dvoch vybraných kanceláriách za prirodzených podmienok. Tieto dve kancelárie sa líšili rozlohou a počtom uživatel'ov. Okrem reálnych meraní bol vykonaný aj dotazníkový prieskum, ktorý bol zameraný na vnímanie rizikových faktorov IEQ samotnými užívatel'mi a na vplyv týchto faktorov na ich komfort a výkonnost' v danom pracovnom prostredí.

Z výsledkov reálnych meraní vyplýva, že obe kancelárie splńajú požadované legislatívne a LEED limity čo sa týka parametrov tepelno-vlhkostne mikroklímy, koncentrácií $\mathrm{CO}_{2}, \mathrm{PM}_{2,5}$ a $\mathrm{PM}_{10}$. LEED limit bol prekročený jedine $\mathrm{v}$ prípade koncentrácií TVOC $\mathrm{v}$ menšej kancelárii, a to nielen počas pracovnej doby, ale najmä po pracovnej dobe, kedy $\mathrm{v}$ tejto kancelárií dochádzalo $\mathrm{k}$ upratovacím prácam. Pre porovnanie, boli merania parametrov IEQ v tejto kancelárii zopakované, aj za neprítomnosti užívatel'ov. Toto porovnanie dokazuje, že koncentrácie TVOC prekročili odporúčaný LEED limit, najmä z dôvodu prítomnosti užívatel'ov v tejto kancelárii.

Z dotazníkového prieskumu vyplynulo, že respondenti vnímajú IEQ v zelenej administratívnej budove pozitívne a toto prostredie považujú za komfortné až vel’mi komfortné. Väčšina respondentov uviedla, že vplyv parametrov IEQ zvyšuje ich výkonnost', prípadne vplyv týchto faktorov vo vzt'ahu $\mathrm{k}$ ich výkonnosti vníma neutrálne. Vzhl'adom na tieto odpovede možno povedat', že bolesti hlavy, únava či letargia, ktoré sa počas pobytu na pracovisku vyskytli u viac ako polovice opýtaných, súvisia viac s druhom vykonávanej práce ako s IEQ.

Celkovo možno konštatovat', že hodnotené kancelárie vybranej certifikovanej budovy poskytujú zdravé a komfortné prostredie, ktoré výrazne neovplyvňuje výkonnost' samotných užívatel'ov.

\section{Pod'akovanie}

Prezentovaný príspevok bol finančne podporený grantovou agentúrou VEGA s číslom grantu 1/0512/20.

\section{Použité zdroje}

[1] HE, Yueer, Thomas KVAN, Meng LIU a Baizhan LI. How green building rating systems affect designing green. Building and Environment [online]. 2018, 133, 19-31 [cit. 2021-11-26]. ISSN 03601323. Dostupné z: doi:10.1016/j.buildenv.2018.02.007

[2] SHAN, Ming a Bon-gang HWANG. Green building rating systems: Global reviews of practices and research efforts. Sustainable Cities and Society [online]. 2018, 39, 172-180 [cit. 2021-11-26]. ISSN 22106707. Dostupné z: doi:10.1016/j.scs.2018.02.034

[3] MATTONI, B., C. GUATTARI, L. EVANGELISTI, F. BISEGNA, P. GORI a F. ASDRUBALI. Critical review and methodological approach to evaluate the differences among international green building rating tools. Renewable and Sustainable Energy Reviews [online]. 2018, 82, 950-960 [cit. 2021-1126]. ISSN 13640321. Dostupné z: doi:10.1016/j.rser.2017.09.105

[4] LEE, Eunsil. Indoor environmental quality (IEQ) of LEED-certified home: Importance-performance analysis (IPA). Building and Environment [online]. 2019, 149, 571-581 [cit. 2021-11-26]. ISSN 03601323. Dostupné z: doi:10.1016/j.buildenv.2018.12.038

[5] WEI, Wenjuan, Pawel WARGOCKI, Johann ZIRNGIBL, Jana BENDŽALOVÁ a Corinne MANDIN. Review of parameters used to assess the quality of the indoor environment in Green Building certification schemes for offices and hotels. Energy and Buildings [online]. 2020, 209 [cit. 2021-1126]. ISSN 03787788. Dostupné z: doi:10.1016/j.enbuild.2019.109683

[6] LEE, Jang-Young, Pawel WARGOCKI, Yiong-Huak CHAN, Liu CHEN a Kwok-Wai THAM. Indoor environmental quality, occupant satisfaction, and acute building-related health symptoms in Green Mark-certified compared with non-certified office buildings. Indoor Air [online]. 2018, 29(1), 112129 [cit. 2021-11-26]. ISSN 0905-6947. Dostupné z: doi:10.1111/ina.12515

[7] LEE, Young S. a Suk-Kyung KIM. Indoor Environmental Quality in LEED-Certified Buildings in the U.S. Journal of Asian Architecture and Building Engineering [online]. 2018, 7(2), 293-300 [cit. 202111-26]. ISSN 1346-7581. Dostupné z: doi:10.3130/jaabe.7.293 
[8] ALTOMONTE, Sergio, Stefano SCHIAVON, Michael G. KENT a Gail BRAGER. Indoor environmental quality and occupant satisfaction in green-certified buildings. Building Research \& Information [online]. 2019, 47(3), 255-274 [cit. 2021-11-26]. ISSN 0961-3218. Dostupné z: doi:10.1080/09613218.2018.1383715

[9] ALTOMONTE, Sergio, Sara SAADOUNI, Michael G. KENT a Stefano SCHIAVON. Satisfaction with indoor environmental quality in BREEAM and non-BREEAM certified office buildings. Architectural Science Review [online]. 2017, 60(4), 343-355 [cit. 2021-11-26]. ISSN 0003-8628. Dostupné z: doi:10.1080/00038628.2017.1336983

[10] JIN, Quan a Holger WALLBAUM. Improving indoor environmental quality (IEQ) for occupant health and well-being: A case study of Swedish office building. IOP Conference Series: Earth and Environmental Science [online]. 2020, 588 [cit. 2021-11-26]. ISSN 1755-1315. Dostupné z: doi: $10.1088 / 1755-1315 / 588 / 3 / 032072$

[11] International Organisation for Standardisation (1998). Ergonómia tepelného prostredia. Prístroje na meranie fyzikálnych veličín (ISO 7726: 1998)

[12] CHEUNG, Toby, Stefano SCHIAVON, Lindsay T. GRAHAM a Kwok Wai THAM. Occupant satisfaction with the indoor environment in seven commercial buildings in Singapore. Building and Environment [online]. 2021, 188 [cit. 2021-11-26]. ISSN 03601323. Dostupné z: doi:10.1016/j.buildenv.2020.107443

[13] LEE, Jang-Young, Pawel WARGOCKI, Yiong-Huak CHAN, Liu CHEN a Kwok-Wai THAM. How does indoor environmental quality in green refurbished office buildings compare with the one in new certified buildings? Building and Environment [online]. 2020, 171 [cit. 2021-11-26]. ISSN 03601323. Dostupné z: doi:10.1016/j.buildenv.2020.106677

[14] TARTARINI, Federico, Stefano SCHIAVON, Toby CHEUNG a Tyler HOYT. CBE Thermal Comfort Tool: Online tool for thermal comfort calculations and visualizations. SoftwareX [online]. 2020, 12 [cit. 2021-11-26]. ISSN 23527110. Dostupné z: doi:10.1016/j.softx.2020.100563

[15] Vyhláška Ministerstva zdravotníctva Slovenskej republiky. Zbierka zákonov č. 210/2016. 2016. O podrobnostiach o požiadavkách na vnútorné prostredie budov a o minimálnych požiadavkách na byty nižšieho štandardu a na ubytovacie zariadenia.

[16] USGB, LEED v4.1 Building Design and Construction Beta Guide, Washington. 2019. Available on: https://www.usgbc.org/resources/leed-v41-building-design-and-construction-beta-guide-january-2019.

[17] USGB, LEED v4.1 Interior Design and construction Beta Guide, Washington. 2019. Available on: https://www.usgbc.org/resources/leed-v41-interior-design-and-construction-rating-system-january2019. International Organisation for Standardisation (2005). Ergonómia tepelného prostredia. Analytické určovanie a interpretácia tepelnej pohody pomocou výpočtu ukazovatel'ov PMV a PPD a kritérií miestnej tepelnej pohody (ISO 7730: 2005) (Norma na priame používanie ako STN).

[18] International Organisation for Standardisation (2005). Ergonómia tepelného prostredia. Analytické určovanie a interpretácia tepelnej pohody pomocou výpočtu ukazovatel'ov PMV a PPD a kritérií miestnej tepelnej pohody (ISO 7730: 2005) (Norma na priame používanie ako STN).

[19] European Standards (2018). Energetická hospodárnost' budov. Vetranie budov. Čast' 1: Vstupné údaje o vnútornom prostredí budov na navrhovanie a hodnotenie energetickej hospodárnosti budov - kvalita vzduchu, tepelný stav prostredia, osvetlenie a akustika. Modul M1-6

[20] Von Pettenkofer M. (1858) Über den Luftwechsel in Wohngebäuden. Der J.G. München: Cotta’schen Buchhandlung. 